Princeton, Ms. L. Virgin of the University of Chicago, and S. Noguchi.

During the colloquium, the Multi-Script Workstation (MSW) for RLIN CJK was demonstrated. An exhibition on the theme of "Byways in Japanese Illustration" was on display in the King's Gallery. Participants also had the opportunity to preview, during the second evening reception, major pieces in the Hyde collection of important Japanese manuscripts and illustrated books before theywere auctioned by Christie's in New York on 7 October.

The final session on the third day included a discussion on the desirability and feasibility of forming a European Association of Japanologist Librarians. Various opinions were exchanged and the further discussion and decision will take place in Berlin, October 1989.

The endeavor of Yu Ying Brown, who is the head of the Japanese Section, Oriental Collection of the British Library, and was the organizer and convener, was very much appreciated by all participants. Copies of the presented papers were distributed at the Colloquium and will later be published as a volume by the British Library.

\title{
Consumers as producers
}

\section{Libra-ies as publishera}

\author{
By Helen MacLam \\ Social Science Subject Editor \\ Choice
}

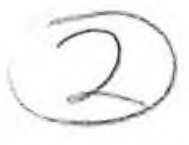

\section{A report on the International Group of Publishing Libraries.}

$\mathbf{A}$

lthough comparatively few in number, libraries with publishing programs occupy a significant, if special, niche in the publishing community. Mainly research facilities, these libraries may be privately funded, such as the Huntington Library; they may be affiliated with a university; or they may be national institutions, such as the Library of Congress or the Koninklijke Bibliotheek, The Hague. Their publications range from major research tools to postcards.

The International Group of Publishing Libraries grew out of a 1983 seminar of library publishing held at the British Library. Representatives from about thirty institutions in the U.S., U.K., and Western Europe gathered to share ideas and expertise hard won from their experiences as publishers. The IGPL, which remains an informal group rather than a formal organization, meets biennially to share experiences and explore the possibilities of active collaboration among research libraries operating publishing programs.

Library publishing has a long if not widely known history. David Way (the British Library) indicates that the Bodleian Library, Oxford, issued its first catalog in 1605, and the first volume of the British Museum's Catalogue of Additions to the Manuscripts (to which volumes are still being added) came out in 1843. Way further states that "Today several libraries operate publishing programs on a scale extensive enough to qualify them as mediumsized publishers: for example, the National Library of Australia and the British Library each issues well over fifty titles a year."

In this country, the Library of Congress and the

'David Way, "Publishing in Libraries." Scholarly Publishing 20, no. I (October 1988), 35. 
New York Public Library are major publishers. LC brought out its first title, a book list, in 1801, and now publishes about thirty titles a year. NYPL has produced a variety of materials, among them, monographs, facsimiles, bibliographies, and exhibition catalogs. According to Richard Newman, director of publications, the NYPL publishing program has been revitalized in the last few years, issuing works that extend from the very scholarly to the very popular, and which reflect holdings from all parts of the library, including the branches. Newman stated that the NYPL has gone a long way in surmounting the financial problems that previously hampered its program.

This past June the International Group of Publishing Libraries conference was held in Edinburgh, hosted jointly by the National Library of Scotland and Edinburgh University Library. The conference was in fact more of a working session, with free exchange on the issues generated by presentations.

In his discussion of library publishing policy, Peter Freshwater (Edinburgh University Library) began by stating objectives that pretty well summarized the goals of IGPL members as a whole: to publicize the collections and services of the library and to promote their use as resources for learning, teaching, and research; to generate income for the library; and to exploit material in the library's collections in order to achieve these objectives. Freshwater also remarked that publication is a conservation measure that gives access to closed collections.

\section{Research in science and technology}

The Forum for Science and Technology Library Research Task Force, a newly formed committee in ACRL's Science and Technology Section, has requested abstracts of recent research or research in progress of interest to science or technology librarianship. The committee will select individuals to present reports of their research at the 1990 Annual Conference in Chicago.

The research should focus on timely, relevant, and significant aspects of science and/or technology librarianship. The proposal should not exceed one page, which will include the researcher's name, institution, phone number, and an abstract not to exceed 250 words. The deadline for submission is December 15, 1989. The participants will be chosen at the Midwinter Meeting. All proposals should be sent to Susan Stewart, Life \& Health/Physical Sciences Librarian, University of Neveda, Reno, NV 89557; (702) 784-6616.
All of the objectives were implicit components of the conference presentations, as were the issues of marketing and distribution, and the physical aspects of production.

A major ongoing concern is preservation, specifically, the need for use of alkaline paper. Gwynneth Evans reported that the National Library of Canada is experimenting with acid-free paper for its parliamentary publications. David Way said the British Library used alkaline paper for the majority of its reference publications and is beginning to use it for other books. There was consensus among U.K. librarians on the importance of cooperating to develop the use of acid-free paper.

Other sessions treated the role of libraries as publishers of scholarly journals (Clive Field, John Rylands University Library of Manchester; Guilland Sutherland, Huntington Library); microform publishing contracts (Kenneth Carpenter, Harvard); and production technology. A brief discussion of copublishing and outside publishing highlighted what Dana Pratt, director of publishing, Library of Congress, had previously referred to as the "OPM factor," i.e., use of other people's money. ${ }^{2}$ These alternatives have also been used successfully by other library publishers, e.g., the New York Public Library.

At a general session open to non-IGPL members, problems of small-scale publishing were addressed by Alison Harley of the Scottish Publishers Association, an organization of about $65 \mathrm{mem}$ bers. Harley identified key problems as sales, marketing, and distribution, saying that a good sales rep is critical because most of the Association's sales are made through bookstores. Andrew Miller (Glasgow District Libraries) related the phenomenal success of one of their publications, Michael Munro's The Patter, a scholarlyyet hilarious dictionary of Glaswegian speech guaranteed to appeal to Scots and anyone of Scottish descent worldwide.

The final presentations covered two other means of promoting collections and generating revenue: bookshops and exhibitions. Jane Carr (the British Library) described the search for a site for the library's bookstore. Several external sites were examined but none was satisfactory. Ultimately, the shop was located in the Grenville Library, opposite the British Museum stores. Although the shop offers a mix of products, Carr believes it could succeed just selling books. Colin Wight (the British Library) said the store sold many reference books, handbooks, and thesauri. He confirmed the value of accepting credit cards: $15 \%$ of the store's sales

${ }^{2}$ David Way, ed., Library Publishing (London: British Library Occasional Papers, no. 2, 1985), 45. 
are paid by VISA; $7 \%$ by Mastercard/Access. Ruth Ann Stewart (Library of Congress) reported on the successful opening of LC's new store, which sells a mix of books, gift items, folk art, juvenalia, and stationary products.

Nigel Thorp (Glasgow University Library) recounted details of the exhibition The Glory of the Page, consisting of Renaissance and illuminated manuscripts from the Glasgow University Library. From initial planning to actual production the exhibition took nearly five years. Thorp personally supervised packing and unpacking at each exhibition site, driving a truck across Canada and North America (an adventure itself worthy of a book).

IGPL will next meet in 1991 in Cambridge, Massachusetts. The conference will be cosponsored by Harvard University and the Massachusetts Historical Society. As Jane Carr put it, "The issues have been raised; now solutions must be explored."
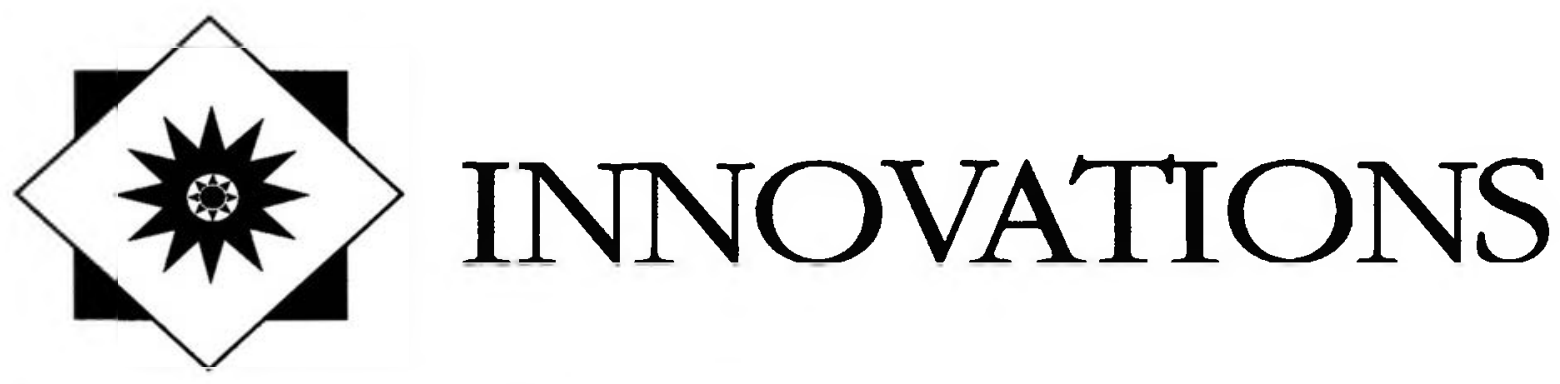

\section{Humor and creativity: Basic technology}

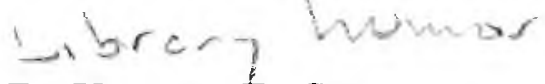

By Norman D. Stevens

Director, The Molesworth Institute
Those among us who are intelligent, and fortunate, enough to have become skilled information professionals have demonstrated that academic

\section{Feeling funny?}

Having taken leave of my peculiar pursuit of library humor for a brief period of time, I find I have become more irritable. Having taken leave of my senses, I have allowed the editor of $C \& R L$ News, and both of the readers who have responded positively to my efforts to date, to persuade me to resume my efforts to enlighten and amuse you by searching out and offering up these tales of creativity and humor in academic librarianship. For the time being my idle threat in the April 1989 issue to leave you to your own devices has been postponed. So I once again renew my quest for appropriate examples of this genre. Please send examples of your creativity, and that of your colleagues, to me at 143 Hanks Hill Road, Storrs, CT 06268 along withyou guessed it-your business card, a postcard of your library, or any other kind of library ephemera. librarians can master the complexities of a new information age with all of its new technologies. CD-ROMs, OPACs, and other mysterious firmware, hardware, software, and even vaporware don't faze some of us. We can hold our own with the other technocrats who have come to dominate academic communities.

Then there are the rest of us. For some academic librarians technology still is, as it has always been, a true test of our mettle. The incredible expertise of our more knowledgeable colleagues may utterly baffle us as we struggle with low technology or the simpler aspects of high technology. Fortunately it is most often the rudimentary aspects of the librarian's love affair with technology that provides us, when we are either frustrated or inspired, with our greatest opportunities to use humor to put technology and technocrats in their proper niche - the vacant recessed nook in the corridors of older libraries once reserved for the bust of Shakespeare.

\section{Paperclips}

That the challenge of the simpler forms of technology is not something new is amply demonstrated by the little known, and seldom recalled, contro- 